\section{JURNAL TEKNIK INFORMATIKA}

Halaman Jurnal: http://jurnal.stmik-dci.ac.id/index.php/jutekin/ Halaman LPPM STMIK DCI : http://Ippm.stmik-dci.ac.id/

\title{
REVIEW OPTIMASI ENERGI PADA PROTOKOL INTERNET OF THINGS (STUDI AWAL PERANCANGAN SISTEM TRACKING KENDARAAN BERBASIS INTERNET OF THINGS)
}

\author{
Nizirwan Anwar ${ }^{1}$, Budi Tjahjono², Masmur Tarigan ${ }^{3}$ \\ Prodi Teknik Informatika Fakultas Ilmu Komputer Universitas Esa Unggul \\ Email : nizirwan.anwar@esaunggul.ac.id ${ }^{1}$, budi.tjahjono@esaunggul.ac.id ${ }^{2}$, \\ masmur.tarigan@esaunggul.ac.id ${ }^{3}$
}

\begin{abstract}
ABSTRAK
Internet of Things adalah salah satu teknologi yang paling cepat berkembang. Dalam hal penggunaan dan inovasi, itu meningkat pesat. Banyak pengembangan sensor, Layanan, dan infrastruktur dilakukan. Karakteristik sistem loT yang berbiaya rendah, energi rendah, dan pemrosesan rendah menimbulkan masalah ketika ada peningkatan jumlah node dan volume data. Dengan banyak produksi (pabrikan) perangkat yang dibangun tanpa memperhatikan standardisasi. Kondisi ini akan menyebabkan sistem turun, mengurangi tingkat keamanan, dan pada akhirnya mengurangi tingkat Kualitas Layanan.
\end{abstract}

Kata kunci: Internet of Things, Optimasi energi, Biaya Rendah, Kendaraan, Tracking.

\section{PENDAHULUAN}

Terdapat 3 (tiga) komponen pembangunan Internet of Things (IOT) yaitu sisi Sensor, Infrastruktur Jaringan (Hardware dan protocol), Layanan/Services. Permasalahan muncul karena perkembangan atau scale-up mulai dari jumlah titik tersambung, volume data terkirim dan kebutuhan level kualitas yang semakin tinggi. Di sisi lain karakteristik dari perangkat adalah low power, low cost, low storage and low processing.

Dari sisi sensor perkembangan didorong oleh perkembangan teknologi elektronika. Semakian banyak fungsi konversi data fisika ke data elektronik yang dilakukan oleh sensor. [1]. Kebutuhan yang meninggkat dari sisi fungsi dan jumlah menyebabkan munculnya perangkat sensor tanpa memperhatikan standarisasi. [2][3]. Implementasi IoT berkembang sesuai dengan dinamika masyarakat. Muncul layanan berbasis IoT baru dan pengembangan seperti smart home, smart farming, e-transportation dan lainnya. [4].

Munculnya Aplikasi berbasis loT akan mendorong pertumbuhan Sensor dan Pengguna. Pertumbuhan tersebut mendorong bertambahnya jumlah 
Nizirwan Anwar, Budi T., Masmur T./ Jurnal Teknik Informatika Vol 8. No. 1 (2020) 51 - 56

koneksi dan aliran data antar node menghasilan kepadatan lalu lintas data yang semakin besar. Antisipasi yang kurang atau salah akan mengakibatkan permasalahan kemacetan jaringan, latency, data hilang dan sistem down. Masalah tersebut juga menurunkan tingkat keamanan sistem dari serangan jaringan.[5]. Infrasturktur loT akan memegang peran penting dalam menjamin kehandalan sistem atau level Quality of Service layak. Terdapat dua komponen utama infrastruktur jaringan yaitu perangkat keras berupa sistem transmisi data dan manajemen jaringan yang di dalamnya adalah protocol. Network protocol yang digunakan jaringan loT adalah memanfaatkan infrastruktur di jaringan computer. Namun dalam perkembangannya muncul protocol yang dibangun menyesuaikan karakteristik dari perangkat dan aplikasi berbasis IoT. protocol yang dibangun juga menyesuaikan karakteristik komponen pendukung IoT dan dapat dijadikan referensi/rujukan dasar dalam penentuan perangkat sensor dan end user equipment.

Permasalahan utama sebagian besar sistem loT adalah bagaimana dapat mengirimkan data dalam waktu yang cukup, sumber daya infrastruktur komunikasi yang terbatas dan konsumsi energi yang minimal. [6]. Cara yang dapat dipergunakan adalah dengan menentukan protocol pengiriman data. Terdapat 2 (dua) permasalahan utama dalam mengukur kehandalan infrastruktur komunikasi yaitu :

1. Kecepatan pengiriman data

2. Optimalisasi konsumsi energi
Kedua faktor tersebut sangat dipengaruhi volume data dan coverage area.

\section{PROTOCOL}

Dalam proses pengiriman data dalam jumlah besar, tujuan dan asal yang banyak, infrastruktur yang heterogen, format data yang beragam perlu sebuah manajemen komunikasi data yang baik. Salah satu bagian adalah penggunaan sebuah mekanisme baku untuk pengiriman data. Mekanisme tersebut terdiri dari alur pengiriman data serta format data terkirim. Mekanisme tersebut dinamakan sebagai Network protocol.

Berkembang banyak Network protocol Standar dari pabrik perangkat komunikasi maupun asosiasi bidang komunikasi. Secara umum protocols dapat didefinisikan sebagai sebuah formal standard yang berisi aturan, prosedur dan format data yang menjadi acuan dalam komunikasi antar dua perangkat atau lebih.

sistem komunikasi loT memiliki karakteristik khusus dibandingkan komunikasi perangkat lain seperti komputer dan smartphone. Standarisasi perangkat yang belum lengkap, perkembangan titik komunikasi yang cepat dan perkembangan perangkat baru dan beragam. Berkembang berbagai macam protocol sesuai dengan kebutuhan sistem IoT yang dibangun. Berbagai jenis protocol muncul seperti data link protocols like NFC, RFID, LTE, $\mathrm{Wi}-\mathrm{Fi}$, Zigbee, etc., and interact with the platform and with the application levels through Internet communication technologies.[2], beberapa protocol yang dikembangkan oleh pabrikan dan perbandingan diantaranya [7]

Perkembangan lain adalah munculnya Middleware yang di 
Nizirwan Anwar, Budi T., Masmur T./ Jurnal Teknik Informatika Vol 8. No. 1 (2020) 51 - 56

dalamnya terdapat desirable protocol with all functionalities. Middleware for an loT provides interoperability between the devices or applications. [8]. Tantangan selanjutnya adalah bagaimana membangun protocol jaringan yang terbuka yang mengacu kepada security, scalability, mobility, and energi management are presented in relation to their corresponding features[9]

Peneltian dan pengembangan protocol akan terus berlanjut seiring dengan perkembangan dari layanan loT, kepadatan lalu lintas (traffic) data, munculnya perangkat perangkat baru. Tuntutan akan kehadalan sistem juga mendorong pengembangan protocol jaringan khususnya untuk loT.

\section{PROTOCOL CLASSIFICATION}

Beragamnya karakteristik protocol dari sisi fungsi, lingkup kerja, interoperabilitas menjadikan banyaknya sudut pandang dalam pengelompokan protocol. Berdasarkan pendekatan OSI Layer terdapat klasifikasi (layer) Transfer protocol, Data Link protocol. Pendekatan fungsi terdapat transfer protocol dan transmission protocol.[9]

Pendekatan klasifikasi protocol yang banyak digunakan adalah membagi menjadi Application protocol dan Transport protocol. Application protocol adalah standar yang mengatur bagaimana data dari Aplikasi/User terkirim ke perangkat komunikasi IoT. Sedangkan Transport protocol adalah standar dalam pengiriman data dari satu titik ke titik yang lain. [8]

$\begin{array}{crr}\text { Untuk } & \text { transport } & \text { protocol } \\ \text { menggunakan } & \text { teknologi } & \text { yang }\end{array}$
berkembang di jaringan secara umum. protocol yang ada di kelompok ini adalah UDP dan TCP. Sedangkan application protocol khsuus berkembang mengikuti perkembangan loT. Beberapa metode pendekatan dalam pengelompokan atau klasifikasi Application protocol dari loT [10] adalah XMPP, MQTT dan COAP. Ketiganya sangat popular dipergunakan sebagai protocol dari Aplikasi loT.

Pengembangan

penelitian

protocol mengacu kepada kebutuhan komunikasi data dan permasalahannya. Constrained Application protocol (CoAP) dikembangkan dengan menambahkan mekanisme re-transmision untuk meningkatkan kehandalan sistem mobile [11]. Protocol Message Queuing Telemetry Transport (MQTT), merupakan protokol yang ber-operasi upper stack TCP/IP dan saat ini dikembangkan dengan menambahkan mekanime SEQ, untuk meningkatkan kualitas data terkirim atau mengurangi data hilang. [10]

Selain terkait dengan kualitas data, pengembangan protocol dilakukan juga untuk meningkatkan optimalisasi energi. Salah satu peneltian adalah mengembangkan routing protocol untuk mengurangi penggunaan energi. [12].

Dalam review protocol loT ini akan focus pada pembahasan energi awareness dari pengembangan protocol. Bagaimana protocol digunakan untuk mengurangi konsumsi energi dari perangat loT.

\section{ENERGI}

Konsumsi energi adalah salah satu permasalahan penting di implementasi Internet of Things. Perangkat loT berukuran kecil, mobile, durasi kerja non-stop, isu sumber daya listrik menjadi permasalahan. Lemahnya jaringan akan mengakibatkan pemborosan bateray perangkat, mekanisme transfer data yang complexity and sophiscated juga membutuhkan lebih banyak energi. 
Nizirwan Anwar, Budi T., Masmur T./ Jurnal Teknik Informatika Vol 8. No. 1 (2020) 51 - 56

Pengiriman data dari sensor ke base station membutuhkan energi dari sensor yang besar [13] loT Network success and performance enhancement depend heavily on optimization of energi consumption that enhance the lifetime of IoT [14]

Penelitian yang berkembang di sisi ini adalah :

1. Bagaimana mengukur kebutuhan energi dari sebuah sistem IoT. [12][3][1]

2. Bagaimana menurunkan konsumsi energi dari perangkat.[6]

3. Bagaimana korelasi antara energy awareness dengan reliability awareness.[14]

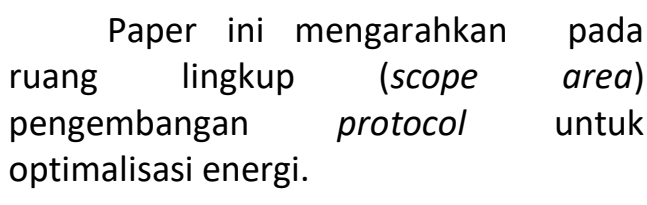

\section{ENERGY MEASUREMENT}

Peneltian terkait dengan optimasi konsumsi energi dalam sebuah sistem harus diawali dengan menentukan alat ukur yang valid dan akurat. Satu metoda pengukuran dengan manambahkan measurement modul di tiap perangkat [15]. Pengukuran dilakukan dengan mengukur daya yang dikonsumsi perangkat dengan variasi protocol WiFi. Hasil pentlitian menunjukkan perbedaan konsumsi energi perangkat antara protocol WPA dan WPA1. Pengukuran energi dilakukan untuk proses transfer data bukan pemrosesan data.

Pendekatan pengukuran lain adalah dengan penurunan model matematik menggunakan probabilitas kegagalan. Penggunaan energi diukur menggunakan peluang kegagalan batterai dalam mendukung proses kerja infrastruktur loT. [3].

VI. ENERGY OPTIMIZER

Efisiensi energi dari sistem berbasis IoT adalah sebuah keharusan. Selain dari perkembangan di sisi elektronika dalam hal penyediaan batteray yang powerfull dan perangkat yang hemat (low) energi, perlu dikembangkan pula mekanisme atau alur pengolahan dan pengiriman data yang optimal.

Penelitian tentang pengembangan efisinsei energi adalah dengan protocol MAC DL. Konsep nya adalah dengan memisahkan sumber data packet loss dan memberikan mekanisme koreksi yang berbeda. Protokol ini menghasilkan life time perangkat yang lebih panjang dibandingkan dengan protocol lain. [16]

Penelitian lain adalah pengembangan protocol Scalable Context-Aware Objective Function (SCAOF). protocol ini membuat sebuah routing framework yang fleksibel for Low-power and Lossy Networks (RPL) [12]. sistem yang dibangun mampu meningkatkan life time dari perangkat.

Pengembangan lain adalah penggunaan IPv6 address autoconfiguration yang merupakan substitusi dari metoda reduksi control message. Protocol ini digunakan di RPL network. [6]

Metoda lain yang dikembangkan adalah Energy Efficient Routing Techniques. Dalam penelitian ini dilakukan perbandingan terhadap beberapa protocol routing. [14]

Semua pengembangan metode optimasi energi dilakukan dengan karakteristik sebagai berikut :

1. Melakukan reduksi beberapa proses atau tahapan yang tidak perlu dalam pengiriman data atau koreksi data. 
Nizirwan Anwar, Budi T., Masmur T./ Jurnal Teknik Informatika Vol 8. No. 1 (2020) 51 - 56

2. Mengembangkan konsep probabilitas jalur atau route terdekat dalam pengiriman data.

3. Penjadwalan perangkat untuk menghemat konsumsi energi.

4. Pengembangan dilakukan melalui modifikasi protocol yang sudah ada.

\section{KESIMPULAN}

Kecepatan perkembangan implementasi loT sangat pesat. Peningkatan jumlah titik, ukuran jaringan dan volume data mengakibatkan peningkatan konsumsi energi yang besar. Kegagalan dalam supply energi akan menurunkan kualitas layanan sistem tersebut. sistem akan down jika sumber energi drop, error akan muncul dan vulnerability akan meningkat jika terdapat perangkat yang energi drop. Perlu sebuah penelitian dan pengembangan yang focus terhadap konsumsi energi.

Selain pengembangan di sisi perangkat elektronik khususnya bateray penyimpanan dan komponen semikonduktor yang hemat energi, pengembangan mekanisme pegiriman data, dalam hal ini adalah protocol dapat menjadi solusi energi efisiensi dari loT.

Masih terbuka lebar penelitian di optimasi konsumsi energi melalui pengembangan potokol. Mengingat variasi dan beragamnya infrastruktur sistem dan perangkat sensor yang ada di IoT.

\section{UCAPAN TERIMAKASIH}

Ucapan terimakasih disampaikan kepada pihak pihak yang membantu pelaksanaan penelitian. Penelitian ini dibiayai oleh Direktorat Riset dan Pengabdian Masyarakat, Direktoriat Jendral Penguat Riset dan
Pengembangan Kementerian Riset, Teknologi dan Pendidikan Tinggi sesuai dengan kontrak Penelitian Nomor 14/AKM/PNT/2019 skema Penelitian Terapan Unggulan Perguruan Tinggi (PDUPT) tahun 2019, kontrak Penelitian 013/SP-P.Multi/LPPM/III/2019, dan mengucapkan terima kasih kepada Bapak Dr. Ir. Arief Kusuma AP, MBA sebagai Rektor Universitas Esa Unggul dan Dr. Ir. Husni S. Sastramihardja, MT sebagai Dekan Fakultas IImu Komputer Universitas Esa Unggul, Ibu Dr. Erry Yudha Mulyani, M. Sc. Sebagai Kepala LPPM Universitas Esa Unggul, serta pada pihak-pihak lain yang tidak disebutkan satu persatu atas dukungan dan bantuannya.

\section{DAFTAR PUSTAKA}

D. Hortelano, T. Olivares, M. C. Ruiz, C. Garrido-Hidalgo, and V. López, "From sensor networks to Internet of Things. Bluetooth low energy, a standard for this evolution," Sensors (Switzerland), vol. 17, no. 2, pp. 1-31, 2017.

A. Bujari, M. Furini, F. Mandreoli, R. Martoglia, M. Montangero, and D. Ronzani, "Standards, Security and Business Models: Key Challenges for the IoT Scenario," pp. 147-154, 2018.

D. Deif and Y. Gadallah, "A comprehensive wireless sensor Network reliability metric for critical Internet of Things applications," Eurasip J. Wirel. Commun. Netw., vol. 2017, no. 1, 2017. 
Nizirwan Anwar, Budi T., Masmur T./ Jurnal Teknik Informatika Vol 8. No. 1 (2020) 51 - 56

K. N. Qureshi, "New Trends in Internet of

Things , Applications, Challenges , and Solutions IoT," Telkomnika, vol. 16, no. 3, pp. 1114-1119, 2018.

A. Yang, Y. Li, F. Kong, G. Wang, and E. Chen, "Security Control Redundancy Allocation Technology and Security Keys Based on Internet of Things," IEEE Access, vol. 6, pp. 50187-50196, 2018.

H. Oh and S. Lim, "Light-weight routing protocol in loT-Based inter-device telecommunication wireless environment," Int. J. Electr. Comput. Eng., vol. 6, no. 5, pp. 2352-2361, 2016.

O. M. Alliance, "Internet of Things protocol Comparison," pp. 1-22, 2018.

Y. J. Dhas and P. Jeyanthi, "A Review on Internet of Things protocol and Service Oriented Middleware," in 2019 International Conference on Communication and Signal Processing (ICCSP), 2019, pp. 0104-0108.

A. Triantafyllou, P. Sarigiannidis, and T. D. Lagkas, "Network protocols , Schemes, and Mechanisms for Internet of Things ( IoT ): Features , Open Challenges, and Trends," vol. 2018, 2018.

H. Cheon, H. Jisu, P. Jin, and G. Shon, "Design and Implementation of a Reliable Message Transmission sistem Based on MQTT protocol in IoT," pp. 1765-1777, 2016. 
Nizirwan Anwar, Budi T., Masmur T./ Jurnal Teknik Informatika Vol 8. No. 1 (2020) 51 - 56 